
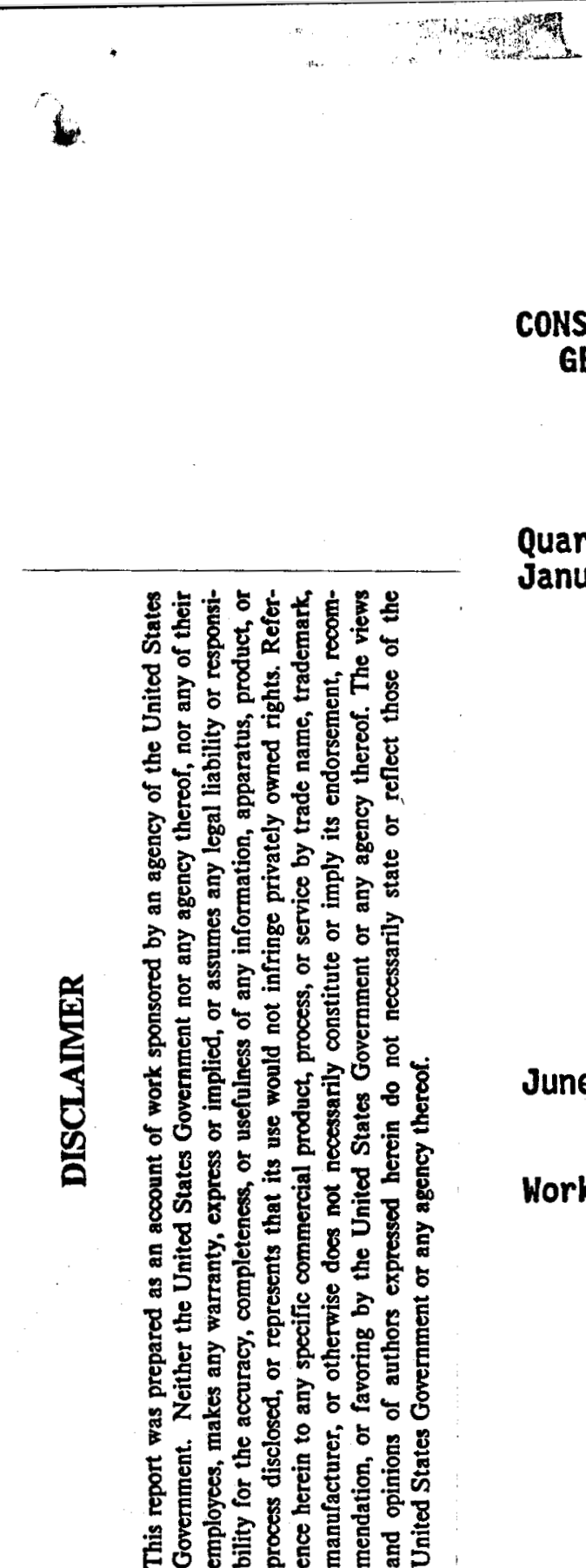

Quarterly Report

January 1993 thru March 1993

\section{GEOPRESSURED-GEOTHERMAL PROGRAM}

\section{June 1993}

Work Performed Under Contract No. DE-FC07-85NV10412
For

U. S. Department of Energy

Office of Industrial Technologies Washington, D.C.

By

Center for Petroleum and Geosystems Engineering Bureau of Economic Geology

The University of Texas

Austin, Texas 78758 


\section{DISCLAIMER}

This report was prepared as an account of work sponsored by an agency of the United States Government. Neither the United States Government nor any agency Thereof, nor any of their employees, makes any warranty, express or implied, or assumes any legal liability or responsibility for the accuracy, completeness, or usefulness of any information, apparatus, product, or process disclosed, or represents that its use would not infringe privately owned rights. Reference herein to any specific commercial product, process, or service by trade name, trademark, manufacturer, or otherwise does not necessarily constitute or imply its endorsement, recommendation, or favoring by the United States Government or any agency thereof. The views and opinions of authors expressed herein do not necessarily state or reflect those of the United States Government or any agency thereof. 


\section{DISCLAIMER}

Portions of this document may be illegible in electronic image products. Images are produced from the best available original document. 


\section{CENTER FOR PETROLEUM AND GEOSYSTEMS ENGINEERING FIRST QUARTERLY REPORT \\ January, February, March 1993}

April 28, 1993

Management Report 79

Report Period: January 1, 1993 - March 31, 1993

CONTRACT TITLE: $\quad$ Consolidated Research Program, United States Gulf Coast Geopressured-Geothermal Program

CONTRACT NUMBER: DE-FC07-85NV10412

CONTRACTOR NAME: Center for Petroleum and Geosystems Engineering

Bureau of Economic Geology

The University of Texas

CPE 2.502

Austin, Texas 78758

CONTRACT PERIOD: . January 1, 1993 - August 31, 1993

RESEARCH AREAS AND CONTRACT TASKS:

Reservoir Engineering

During the past quarter, water influx calculations for the Gladys McCall reservoir have been conducted based on three commonly applied water influx models. The purpose is to identify the possible aquifer geometry and influx function responsible for observed pressure maintenance. Results showed that none of these influx models can match the entire history of Gladys McCall reservoir. Buildup test data also indicates that aquifer may behavior differently during the reservoir production and buildup periods. Our current Gladys McCall influx model is that water leaks through a partially sealing fault into the reservoir under steady-state conditions. Moreover, the transmissibility of the fault is a function of the pressure difference between the aquifer and the reservoir. The match is good but this model needs further investigation.

The pressure behavior of a reservoir under water drive is dependent upon the rate of reservoir fluid withdrawal and upon the rate of water encroachment. In response to a pressure drop in the reservoir, the surrounding aquifer supplies a source of water influx into the reservoir. A reservoir material balance equation can be written as

$$
V_{p} c_{t} \frac{d P}{d t}=q_{e}-q_{p}
$$

where $V_{p}$ is the reservoir pore volume, $c_{t}$ is the total reservoir compressibility, $q_{e}$ is the rate of water influx, and $q_{p}$ is the well production rate. Integrating Eq. 1 with respect to time yields the cumulative water influx, We:

$$
W e(t)=\int_{0}^{t} q_{e} d t=-v_{p} c_{t}\left(p_{0}-p\right)+\int_{0}^{t} q_{p} d t
$$


where $p_{0}$ is the initial reservoir pressure. Equation 2 can be used to calculate aquifer influx from reservoir pressure data and production data. The reservoir pressure and brine production of Gladys McCall reservoir are illustrated in Fig. 1 as a function of time. Water influx history obtained from material balance calculations is also plotted.

The flow of aquifer water into a reservoir is modeled in the same way as flow of oil from a reservoir into a well. Influx is calculated by solving the diffusivity equation using the pressure at the reservoir-aquifer contact as the aquifer inner boundary condition. It is also assumed that the pressure at reservoir-aquifer contact can be represented by reservoir pressure at all times. In our study, three influx models commonly applied in evaluating the performance of hydrocarbon reservoirs have been investigated. They are

1. Transient influx considering both radial (van Everdingen and Hurst 1949) and linear (Miller, 1962; and Nabor, 1964) aquifer geometry.

2. Pseudosteady-state influx (Fetkovitch, 1971).

3. Steady-state influx (Schilthuis, 1936).

Cumulative water influx obtained from each method was compared with cumulative field influx to identify the possible influx model of Gladys McCall.

\section{Transient influx}

van Everdingen and Hurst (1949) derived the constant terminal pressure solution for single-phase radial flow. The solution can be expressed in terms of cumulative water influx as

$$
\mathrm{W}_{\mathrm{e}}=\mathrm{UDp} \mathrm{W}_{\mathrm{D}}\left(\mathrm{t}_{\mathrm{D}}\right)
$$

where $U$ is the dimensional constant for aquifer geometry, $D p$ is the pressure drop at reservoir-aquifer boundary, $W_{D}$ is the dimensionless cumulative water influx function for radial shaped aquifer, and $t_{D}$ is the dimensionless time. Dake (1978) replotted van Everdingen and Hurst's $W_{D}$ function as a function of dimensionless time for finitebounded aquifer and infinite aquifer cases. The definitions of dimensional geometry constant, $\mathrm{U}$, and dimensionless time, $t_{D}$, were also given.

The water influx for a linear model can also be calculated using Eq. 3 by replacing the radial $W_{D}$ function with a linear $W_{D}$ function. Miller (1962) developed linear influx solutions for infinite and finite-sealed aquifers. Later, Nabor and Barham (1964) added the influx solution for a finite linear aquifer with constant pressure at aquifer outer boundary.

To perform influx calculations, it is conventional to divide the reservoir pressure curve into a series of discrete time steps. Superimposing the step influxes gives the cumulative water influx. Vogt and Wang (1990) presented an accurate working formula of Eq. 3 as:

$$
W e\left(t_{D n}\right)=U\left(-W_{D}\left(t_{D n}\right) \frac{p_{1}-p_{0}}{t_{D 1}}+\Sigma_{j=1}^{n-1}\left(\frac{p_{j}-p_{j-1}}{t_{D j}-t_{D j-1}}-\frac{p_{j+1}-p_{j}}{t_{D j+1}-t_{D j}}\right) W_{D}\left(t_{D n}-t_{D j}\right)\right)
$$

where subscripts $\mathrm{j}$ and $\mathrm{n}$ denote the time step. Since all the variables required to calculate the water influx (Eq. 4) are unknown except the pressure, different sets of aquifer geometry data have tested through a trial and error procedure in order to match or to get 
close to the observed pressure behavior. In Figs. 2 to 6, transient influxes for radial and linear aquifers are plotted and compared to actual influx. A range of aquifer sizes and aquifer permeabilities have been used. The match is poor for both infinite models, especially for influx during the reservoir buildup period. Model results show water migrates from reservoir back to aquifer during this period resulting in decrease cumulative water influx. This is not what was observed.

\section{Pseudosteady-state influx}

For an arbitrary geometry aquifer of finite extent in contact with a reservoir, it can be shown that at sufficiently large time water influx rate reaches a pseudosteady-state (Fetkovitch, 1971) such that:

$$
\mathrm{q}_{\mathrm{e}}=\frac{\mathrm{dWe}}{\mathrm{dt}}=\mathrm{J}\left(\mathrm{p}_{\mathrm{a}}-\mathrm{p}_{\mathrm{r}}\right)
$$

where $\mathrm{J}$ is the aquifer productivity index, $\mathrm{p}_{\mathrm{a}}$ is the average aquifer pressure, and $\mathrm{p}_{\mathrm{r}}$ is the reservoir pressure. The working formula for pseudosteady-state influx can be found in Dake (1978). Figures 7 and 8 show results for various aquifer sizes. A relatively large aquifer can easily match the influx during the reservoir production period by choosing a proper value for J, but it will overestimate the flux during the reservoir buildup period, as illustrated in Fig. 7 ( $\mathrm{J}=7.3$ curve). On the other hand, a small enough aquifer can improve the match to early buildup time, but eventually will underestimate the influx at later buildup time, as shown in Fig. 8 .

\section{Steady-state influx}

For the steady-state influx model, the influx equation is similar to that of pseudosteady-state:

$$
\mathrm{q}_{\mathrm{e}}=\frac{\mathrm{dWe}}{\mathrm{dt}}=\mathrm{J}\left(\mathrm{p}_{\mathrm{i}}-\mathrm{p}_{\mathrm{r}}\right)
$$

where $p_{i}$ is the initial aquifer/reservoir pressure. Again, shown in Fig. 9, steady-state influx can't match the entire field data.

It seems that Gladys McCall aquifer acted differently during the production and buildup periods. Therefore, there is no single influx model which seems to be able to fit the entire field influx history. Our current hypothesis is that the transmissibility at aquifer-reservoir boundary is a function of the pressure difference between the aquifer and the reservoir. This model was successfully used by Mr. Shook to match the production history of the Pleasant Bayor reservoir. Good influx match is achieved with this model with a great range of aquifer sizes. Figure 10 shows one of the cases we have tried. Work is proceeding on verification of this model.

\section{Reference}

Ambastha, A.K., Mcleroy, P.G., and Gradér, A.S.: "Effects of A Partially Communicating Fault in A Composite Reservoir on Transient Pressure Testing," SPEFE (June 1989) 210-18.

Dake, L.K.: Fundamentals of Reservoir Engineering, Elsevier Scientific Publishing Co., New York, (1978), Chap 9. 
Fetkovitch, M.J.: "A Simplified Approach to Water Influx Calculations-Finite Aquifer Systems," J. Pet. Tech. (July 1971) 814-28.

Miller, F.G.: "Theory of Unsteady-State Influx of Water in Linear Reservoirs," J. Inst. Pet. (Nov. 1962) Vol. 48, No. 467, 365-79.

Nabor, G.W. and Barham, R.H.: "Linear Aquifer Behavior," J. Pet. Tech. (May 1964) 561-63.

Schilthuis, R.J.: "Active Oil and Reservoir Energy," Trans., AIME (1936) 118, 33-37.

van Everdingen, A.F., and Hurst, W.: "The Application of the Laplace Transformation to Flow Problems in Reservoirs," Trans., AIME (Dec. 1949) 186, 305-24.

Vogt, J.P. and Wang, B.: "A More Accurate Water Influx Formula with Applications," J. Can. Pet. Tech., (July-Aug. 1990) Vol 29, No. 4, 52-62.

\section{Geological Studies}

During the first quarter of 1993, work on geologic studies for the Gulf Coast Geopressured-Geothermal Program involved final editing of a Bureau Geological Circular and geological and engineering analysis of field data for Prado field, a large medium-oil field from the Mirando Trend, South Texas.

The Bureau Geological Circular entitled Geothermal and Heavy-oil Reservoirs in Texas: Direct Use of Geothermal Fluids to Enhance Recovery of Heavy Oil is in final manuscript processing. All figures have been drafted and the manuscript has been written and edited. Final document paste-up is underwily.

During the first quarter of 1993, research concentrated on geologic and engineering characterization of Prado field, Jim Hogg County, Texas. The geophysical logs acquired for Prado field are being analyzed in order to characterize the producing reservoirs. There are five separate producing reservoirs in the field. The following data have been interpreted from existing logs for each reservoir: net sandstone, percent sandstone, structure, isopach, and SP log facies. Both regional and field-specific cross sections have been constructed to show the internal sand-body relationships. A series of maps (structure, net sandstone, percent sandstone, isopach) have been generated using a computerized geographic information system (ARCInfo). Computer manipulation of geologic and engineering information has greatly enhanced the speed of analyzing and preparing the large amounts of data map products. Current activity involves creating a digital GIS system for mapping well log attributes and geologic parameters such as net sandstone, percent sandstone, isopach, and structure of the producing reservoirs within the field.

Findings to date include: (1) Prado field is defined by a combination structural/stratrigraphic trap as a result of updip pinchout of reservoir sandstone and subtle arching by differential compaction of reservoir sindstones over barrier core sandstones; (2) internal reservoir heterogeneity is complex as a result of depositional facies variations and small-scale faulting; (3) reexploration of the field must rely on careful location of bypassed reservoir compartments. 


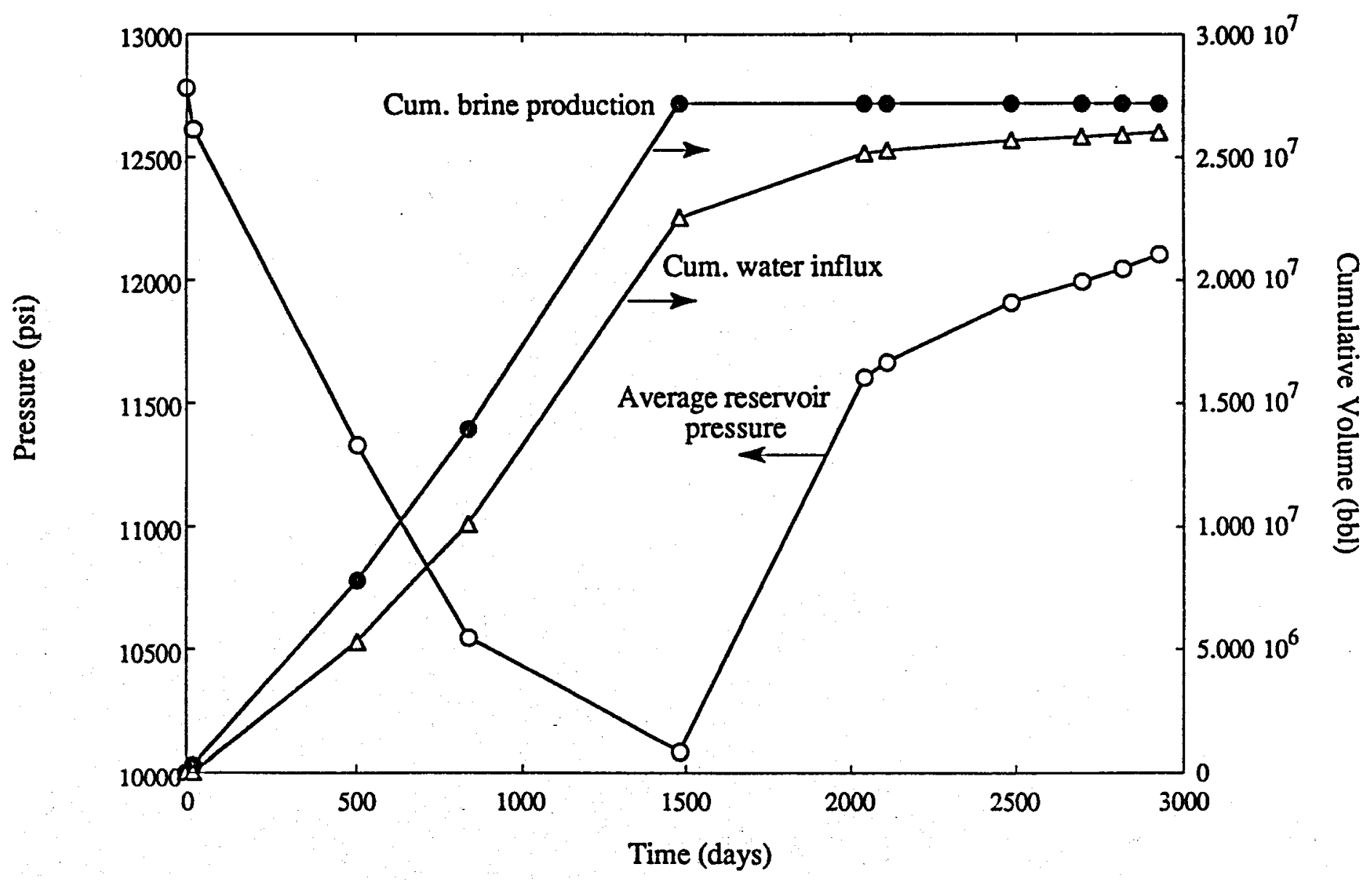

Fig. 1: Gladys McCall reservoir production and buildup history. 


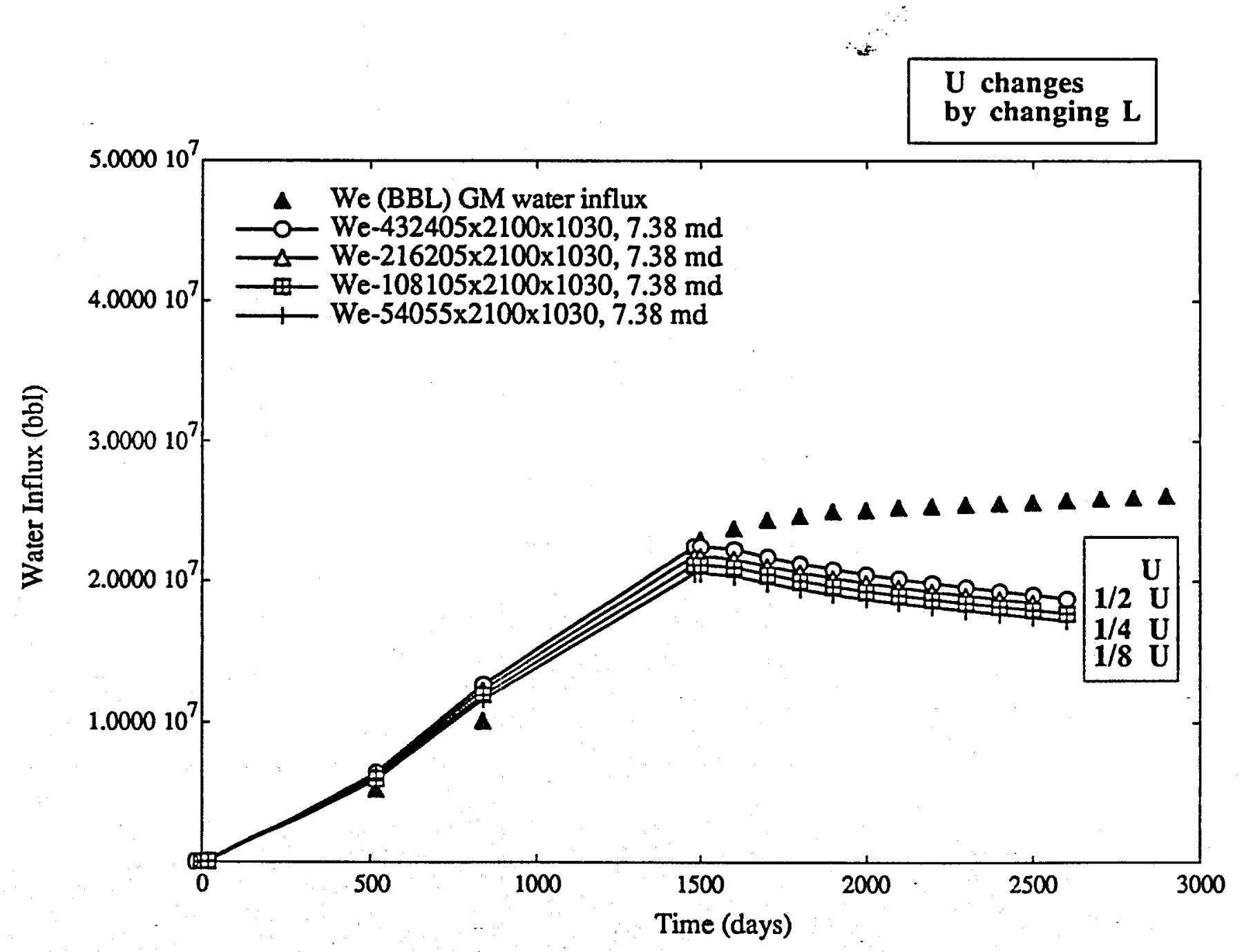

Fig. 2: Water influx for infinite linear aquifer models with different aquifer lengths; $U=0.1781 w \operatorname{wh} \phi C_{t}, t_{D}=0.0002637 \mathrm{kt} /\left(\phi \mu C_{t} L^{2}\right)$. 


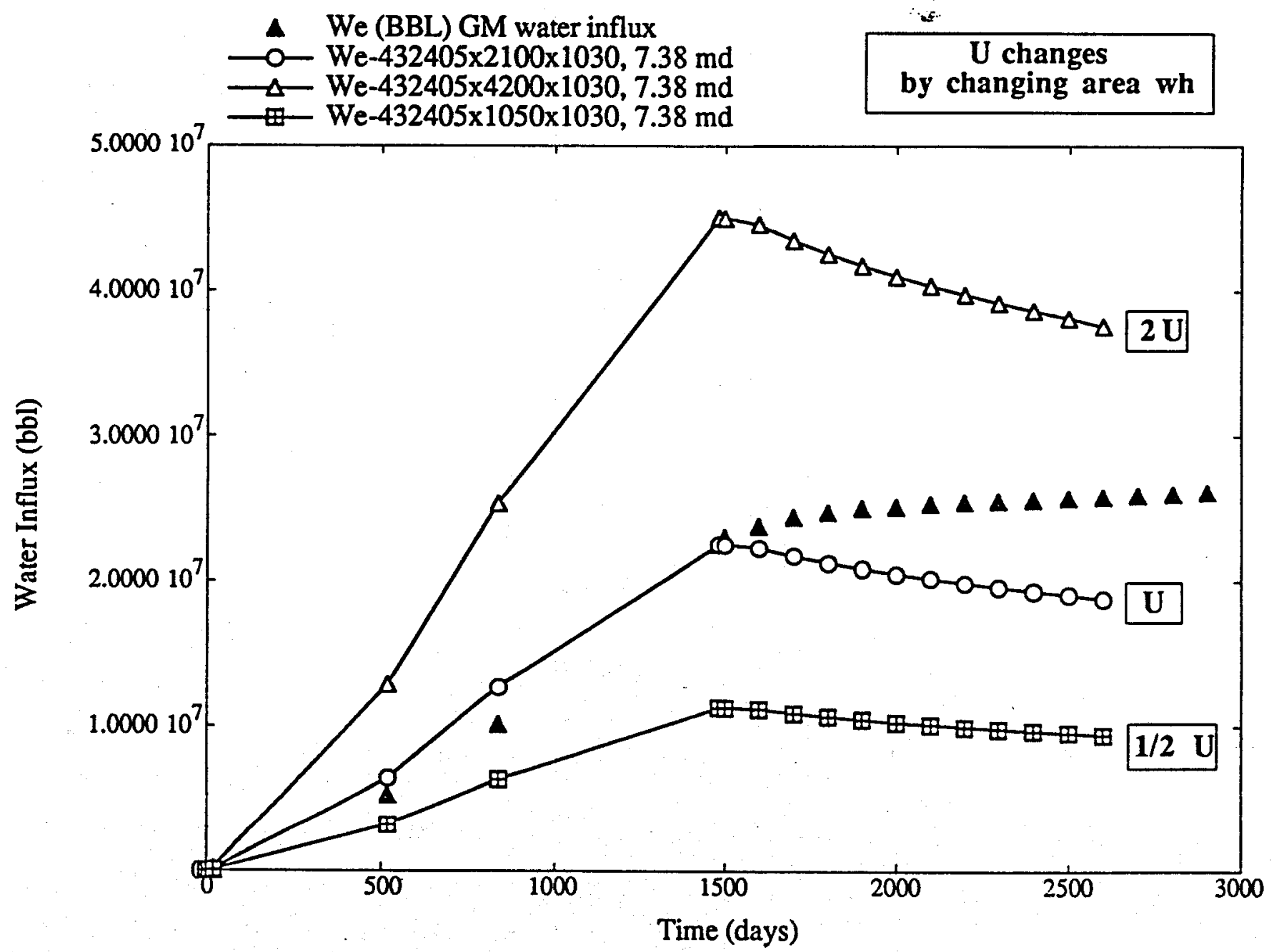

Fig. 3: Water influx for infinite linear aquifer models with different cross-sectional areas; $U=0.1781 w L h \phi C_{t}, t b=0.0002637 \mathrm{kt} /\left(\phi \mu C_{t} L^{2}\right)$. 


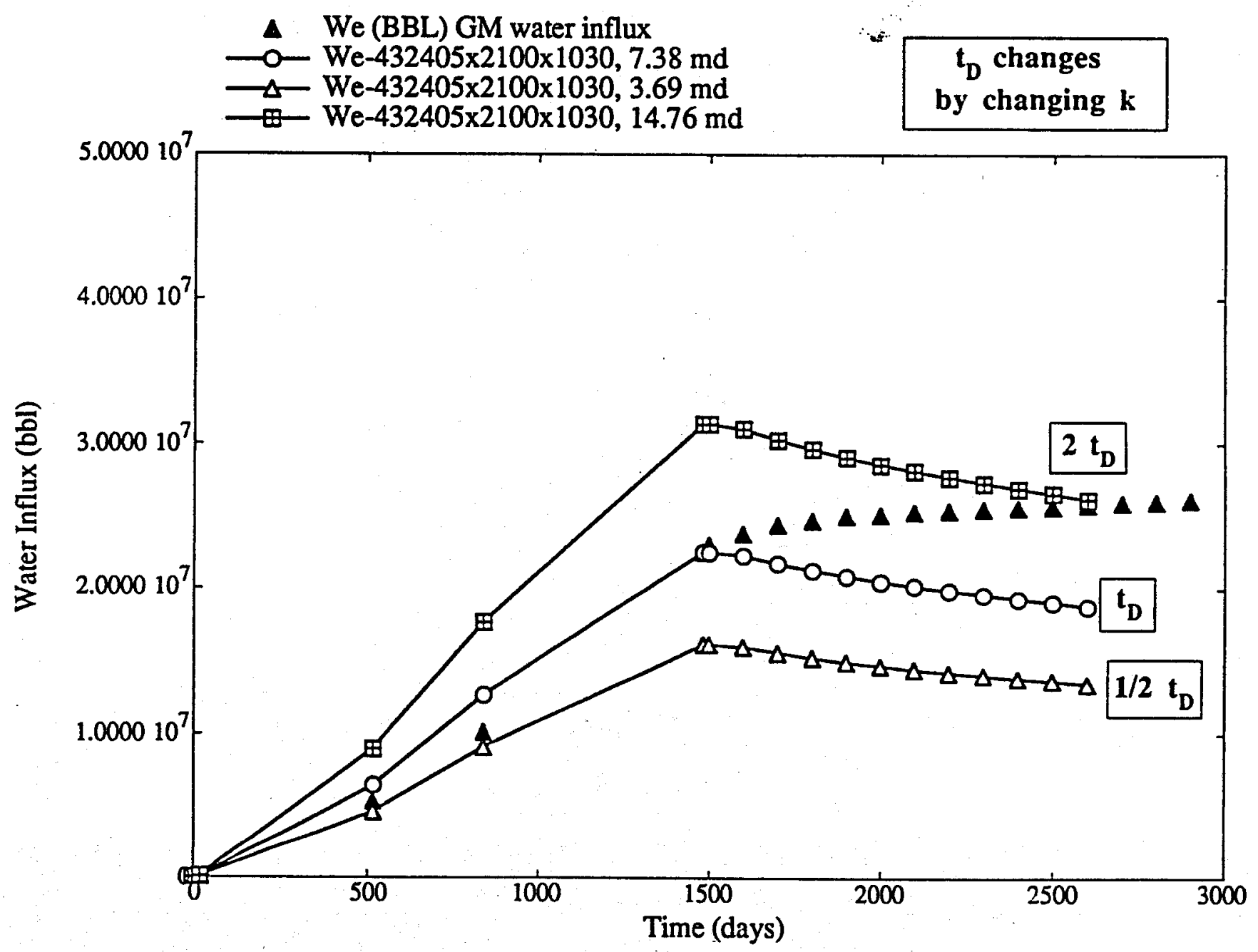

Fig. 4: Water influx for infinite linear aquifer models with different aquifer permeabilities; $U=0.1781 w \operatorname{Lh} \phi C_{t}, t_{D}=0.0002637 \mathrm{kt} /\left(\phi \mu C_{t} L^{2}\right)$. 


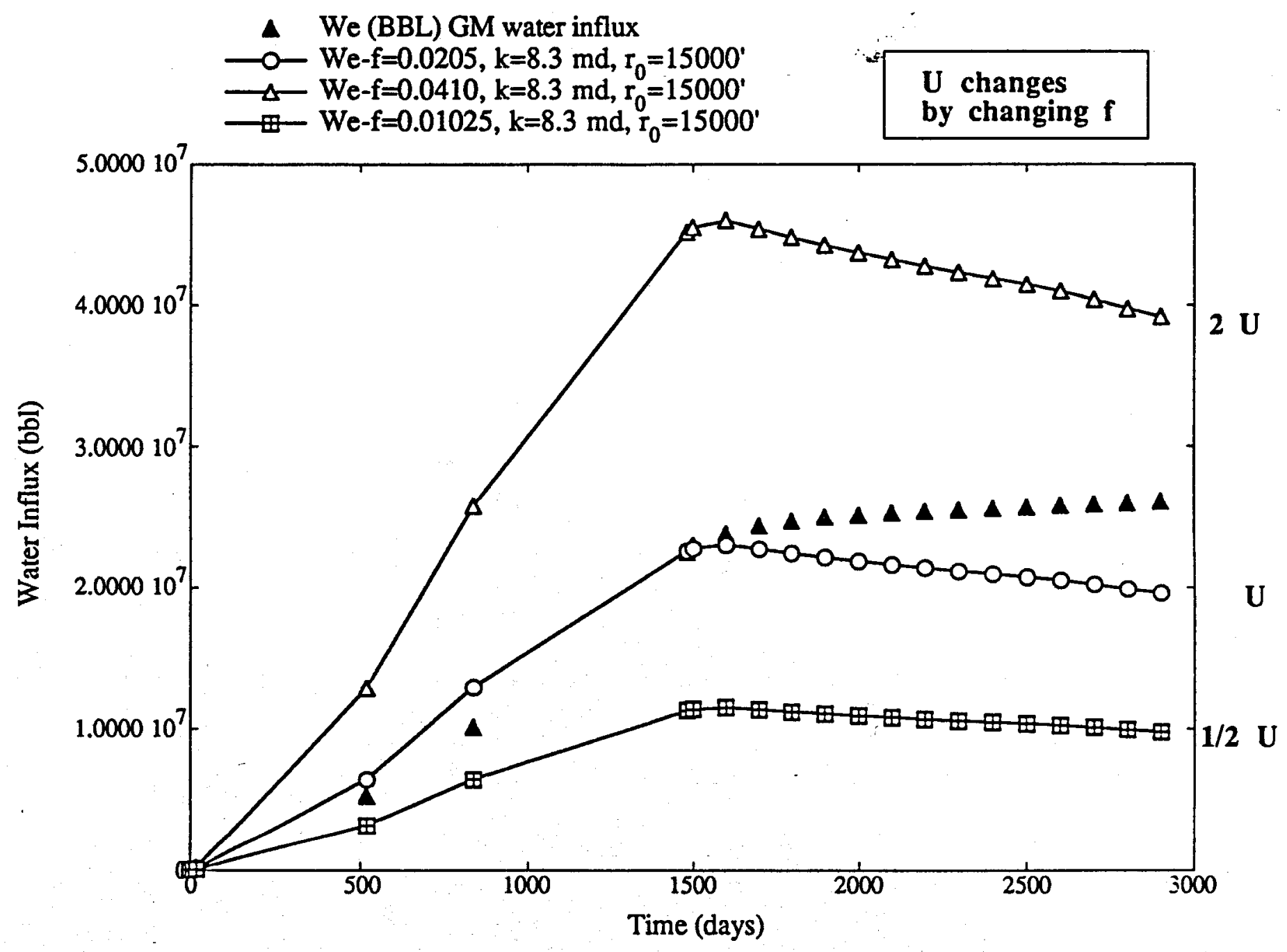

Fig. 5: Water influx for infinite radial aquifer models;

$$
\mathrm{U}=1.119 \mathrm{f} \phi \mathrm{C}_{\mathrm{t}} \mathrm{r}_{0}{ }^{2}, \mathrm{t}_{\mathrm{D}}=0.0002637 \mathrm{kt} /\left(\phi \mu \mathrm{C}_{\mathrm{t}} \mathrm{r}_{\mathrm{o}}{ }^{2}\right) \text {. }
$$




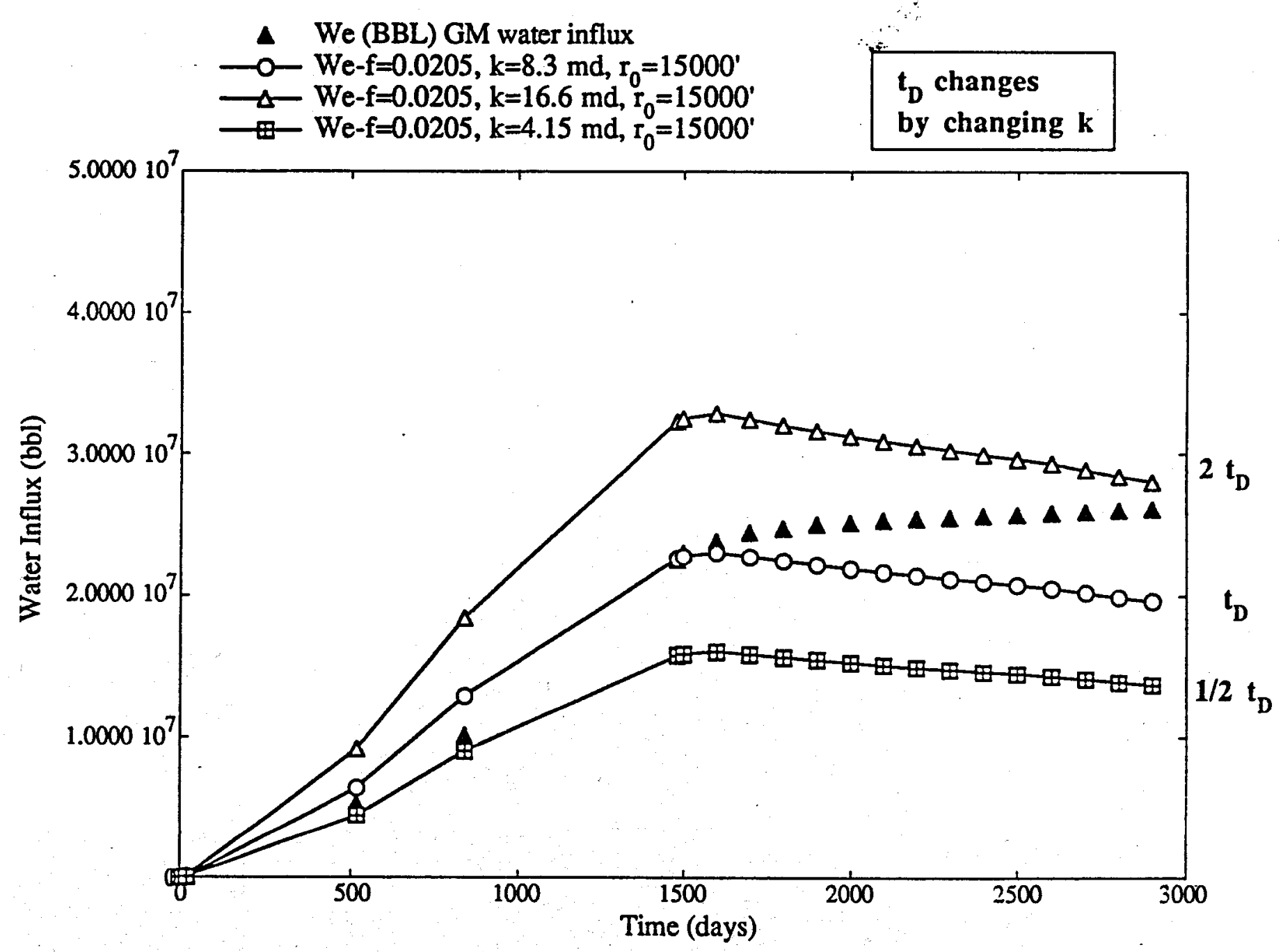

Fig. 6: Water influx for infinite radial aquifer modes with different aquifer

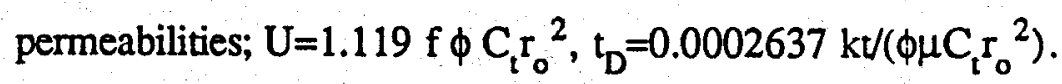




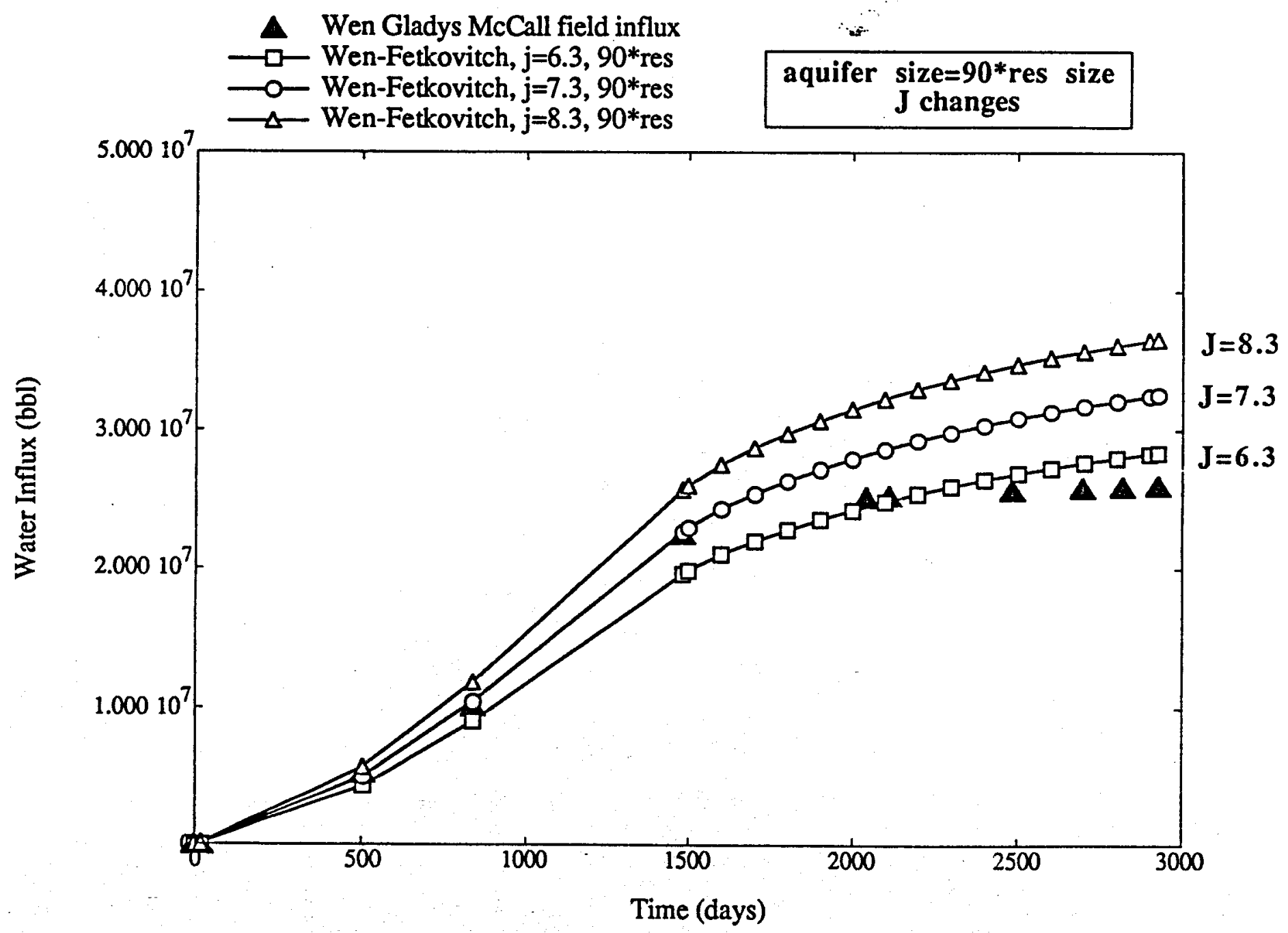

Fig. 7: Water influx for pseudosteady-state models with different J's; aquifer size is 90 times the reservoir size. 


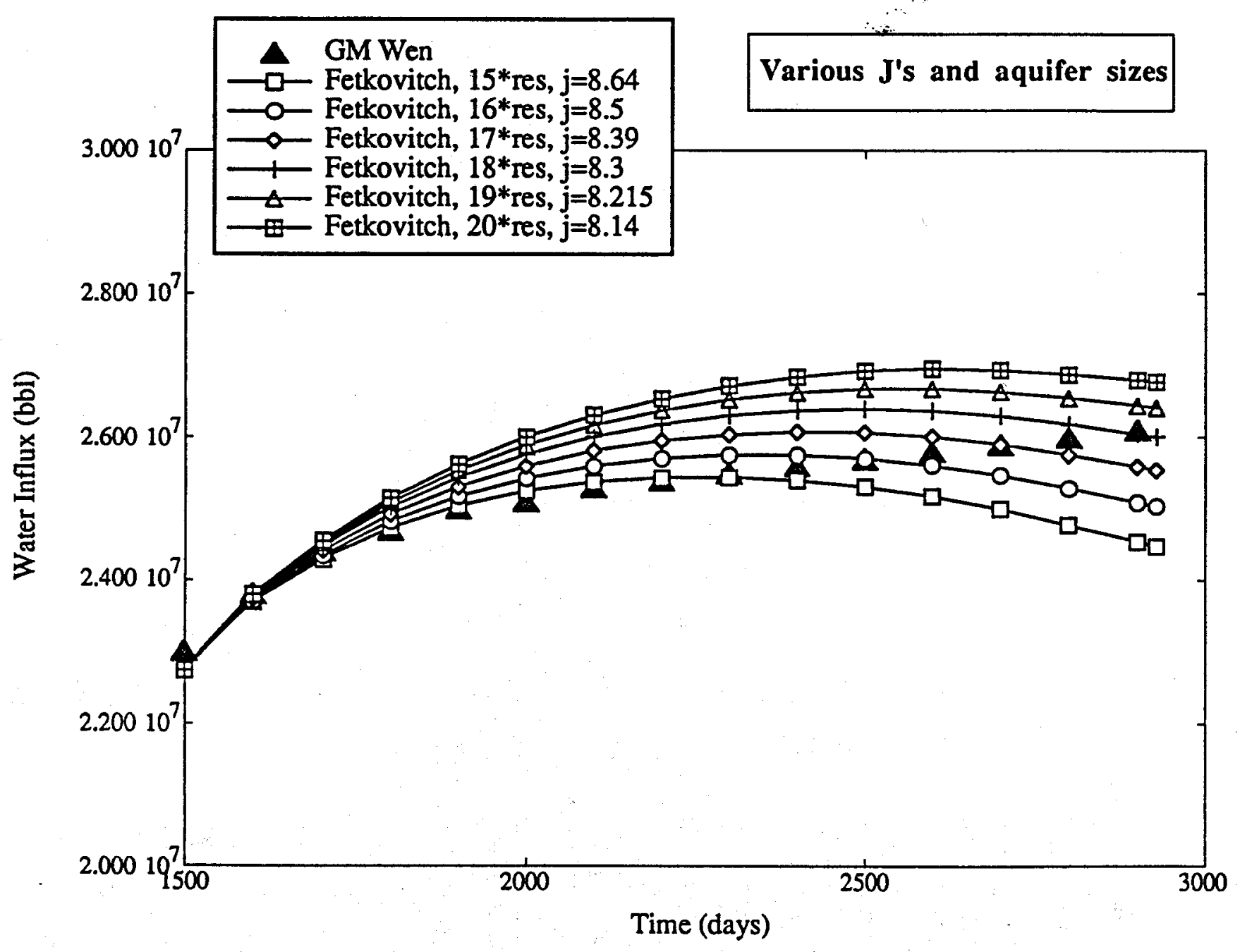

Fig. 8: Water influx for pseudosteady-state aquifer models with various aquifer sizes and J's. 


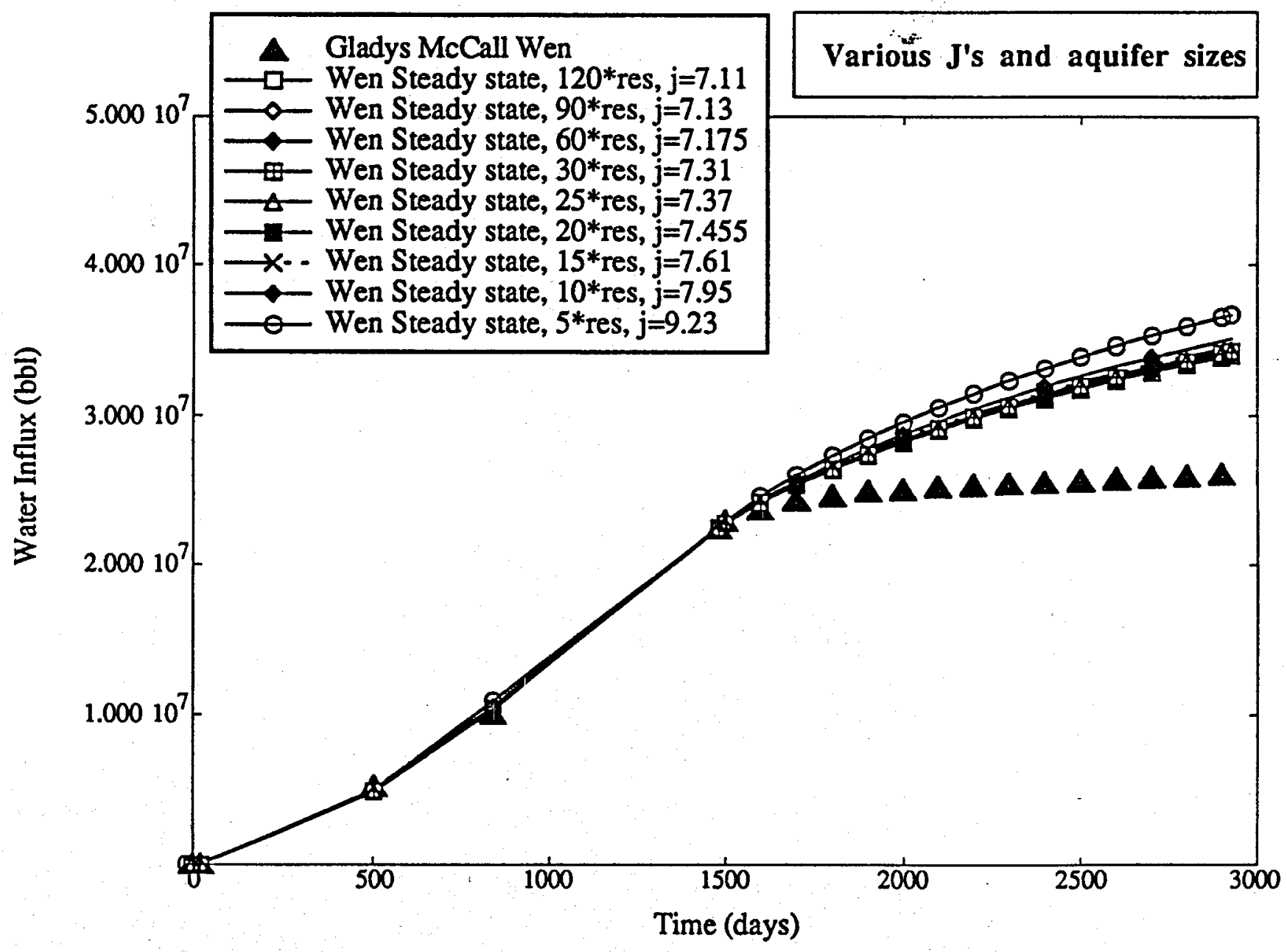

Fig. 9: Water influx for steady-state aquifer models; various reservoir sizes and J's. 


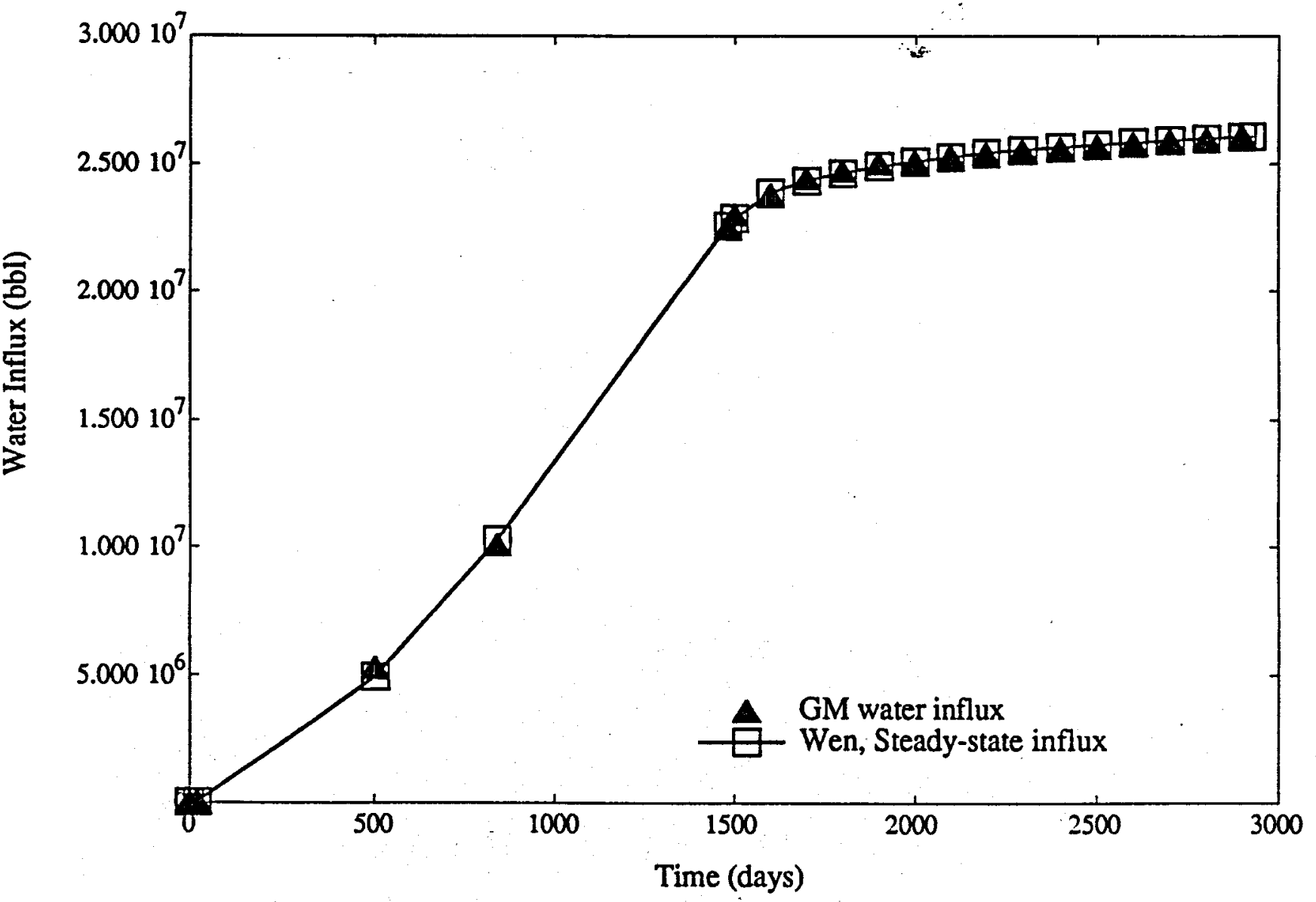

Fig. 10: Water influx for steady-state influx model:

$\mathrm{J}$ is a function of $(\mathrm{Pa}-\mathrm{Pr})$. 